\title{
Social Protection of Population as a Condition for Sustainable Competitive Region Development
}

\author{
Leyla Mytareva \\ Volgograd State University \\ Institute of Economics and Finance \\ Volgograd, Russia \\ mytarevala@volsu.ru
}

\author{
Lyubov Grigoryeva \\ Volgograd State University \\ Institute of Economics and Finance \\ Volgograd, Russia \\ grigorievalv@volsu.ru
}

\begin{abstract}
Sustainable competitive region development is impossible without creation of effective mechanisms for social protection of population, since the territory human capital is the goal, instrument, and result of region's social and economic policy. Taking into account federal policy of Russia, most of powers in social protection field are delegated to regional and municipal levels. Regional and municipal authorities perform the assigned powers based on the available financial resources at their disposal, and this fact generates high regional differentiation in terms of social protection level provided. Unified approach is required in terms of revision of certain paternal system aspects of the population social protection from the perspective of enhancing efficiency, expediency and targeting, as well as reorientation to new models of social protection based on partnership between the state, business and society. However, current social protection system is structurally cumbersome, nontransparent, and confusing at the normative level. And with this understanding, the author gives the definition of the population social protection system, considers federal and regional social support measures. Further the author proposes and justifies directions for the formation of regional social protection system from the point of its place and role in sustainable and competitive development of Russian regions.
\end{abstract}

Keywords - social protection, population, region, competitive development, social code, social protection targeting

\section{INTRODUCTION}

Any territorial formation with the status of an independent economic entity a priori enters into competitive struggle for economic resources (financial, entrepreneurial, labor, etc.) [1]. In modern economics, a person (human resources, capital) is considered simultaneously as a goal, instrument and result of social and economic development. And then the level of population social protection of a particular region becomes an indicator of its social security as well as necessary condition and result of sustainable competitive territory development.

Key issues of this research can be illustrated by two aspects. Firstly, Russian theory and practice considers the category of population social protection in unjustifiably narrow sense. It includes social care (based on social services), social security in the form of social insurance (where the final result is the provision of pensions and benefits) and social assistance (provision of benefits and welfare payments to certain categories of the population). We consider the social protection system of the population in a broader manner, based on not only the legal consolidation in national law but on its social and economic nature. Secondly, the federal polity of Russia imposes certain restrictions on the procedure of social protection measures formation and financing for Russians residing in different regions of the Russian Federation.

The aim of the article to identify the main directions for regional social protection system improvement from the position of shaping conditions for competitive development of regions, drawing on system approach to the social protection of Russians and degree of regional differentiation of social protection system.

The aim achievement assumes the following points: 1) to give the author's definition of the social protection system of region population; 2) to describe the current state of social protection system for Russians, which will assist to reveal its differentiation and major problems; 3) to reveal the basic directions of social protection system improvement with an emphasis on the regional component.

\section{MATERIALS AND METHODS (MODEL)}

The research normative and legal base was represented by the normative and legal regulation documents of social protection system of Russians.

The research empirical base includes official data of following agencies: federal, regional and local executive authorities; Ministry of Labor and Social Protection of the Russian Federation, Federal State Statistics Service, Pension Fund of the Russian Federation; open access media data, Internet sources, particularly the Unified State Information System for Social Security (ESSISO).

The research methodology is represented by system approach to the nature and structure definition of population social protection. The authors use methods of comparative analysis, tabular and graphical data processing methods to identify the differentiation of regions in terms of social protection indicators. Another branch of methods includes the method of abstraction and synthesis while identifying the key problems of differentiation of regions in terms of social protection indicators,

\section{RESULTS AND DISCUSSION}

A. The authors' definition of social protection system of region's population

The authors' approach to social protection system substance draws on the following components: 1) the terminological content of the category "social", which can be described as a conscious, human interaction, established in a more or less constant group [2], and expressed in relations between groups of people occupying different positions in society [3], and formed in terms of the status and role positions of social interaction direct participants [4];2) the possibility to synthetically figure out the social protection system content, based on the economic nature of the state social function, as well as on the analysis of Russian legislation in the sphere of constitutional rights 
of Russians to be protected in the field of labor relations (conditions, protection and remuneration of labor, employment), different types of social provision and insurance, protection of maternity, childhood, social guarantees in terms of health, education, culture, ecology; 3) Russian federal polity specificity, which determines the budget system division into federal, regional and local levels, with specialized off-budget funds functioning at the federal and regional levels (for instance, the Russian Pension Fund, the Mandatory Health Insurance Fund, the Social Insurance Fund and their territorial branches).

The authors suggest that social protection system should be understood as state and municipal authorities activity (on both federal and regional levels) aimed at free personal development formation as well as providing individual with possibility to self-determination and creating conditions for decent life of the citizens. There are two types of legally and economically justified guarantees, which should be used to ensure such activity: general minimum guarantees for all citizens and specific social guarantees and benefits for certain categories (groups) of citizens (usually socially vulnerable and / or socially significant ones) (see Figure 1).

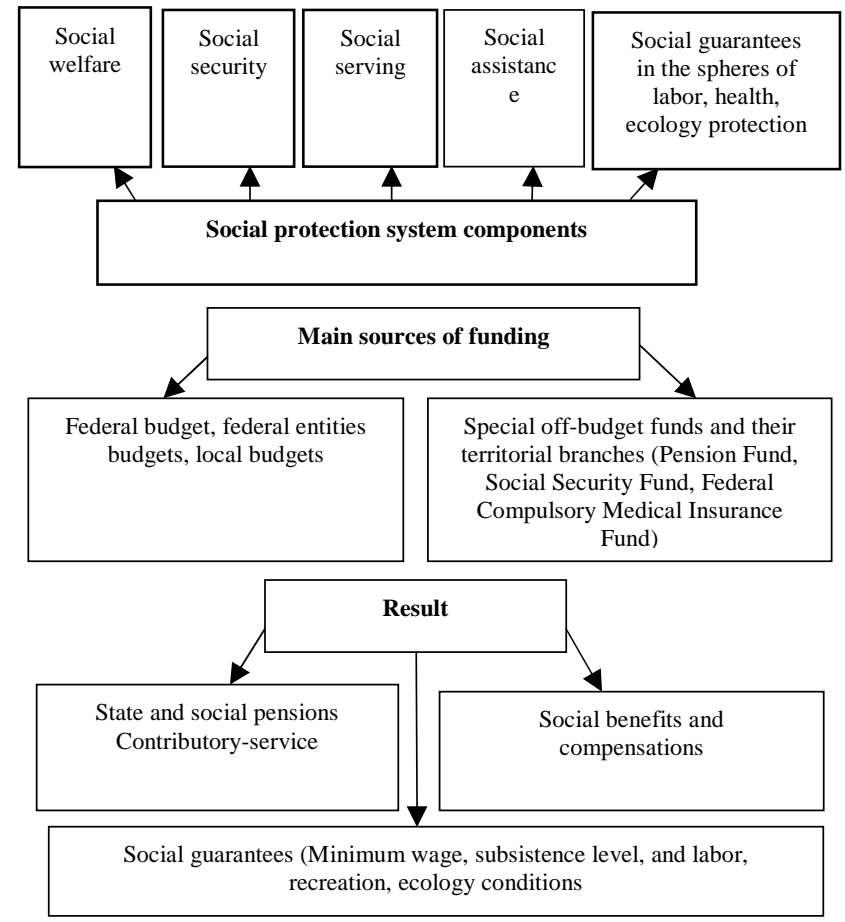

Fig. 1. Social protection of population in modern Russia

Therefore, the whole population (all of its categories) living in specific territory acts as the social protection object, but its most vulnerable layers and those with currently generally recognised high value for the state (municipality) or the need for assistance and protection from the state (municipality) are foreground.

B. Current state of social protection system of Rusians on the federal and regional levels

All social protection measures of Russians can be divided into federal, regional and local ones in terms of establishment. As a rule, if regional and local budgets do not have enough funds to finance social protection measures at the rate set by federal authorities, they receive subsidies for surcharges that bring the funding regional level to the federal minimum.

The current social assistance system in Russia is complicated and cumbersome: there are about 800 measures for 300 categories of recipients, among which the following enlarged groups can be highlighted: "For meritorious service for the state" - 139 measures and 37 categories of recipients; "For special working conditions" (ensuring the attractiveness of the civil service or service in high risk environment) - 117 measures and 82 categories of recipients; "Compensation for harm, loss, damage" - 450 measures and 131 categories of recipients. Among these groups there can be identified another ones, "Labor Veterans" - 9 million citizens, "Regional Labor Veterans" - 4 million, "Rural specialists" - 1.5 million [5]. As a result, 7 out of 10 Russians receive social assistance if pensions and benefits are taken into account; only 4 out of 10 Russians receive benefits (i.e. $42 \%$ of Russians who fall into one of almost 300 categories of recipients) [5]. As a result, state social programs cover $71 \%$ of Russians.

The minimum wage, which is set at the federal and regional levels, is one of the most important social protection measures that covers the whole population. That means that employers must pay their full-employment employees no less than the minimum wage level. Employers who violate law pay an administrative fine. In addition, there is a number of other payments calculated from the minimum wage, the minimum level of which is also guaranteed by the state. For instance, temporary disablement allowance, maternity, childcare up to 1.5 years, and numerous other social payments. The minimum wage changes often. Federal entities has the right to establish the regional minimum wage and it applies to the regional minimum wage level [6].

Therefore, in the year to 2017 in Russia, the federal minimum wage was established at 7800 rubles per month. It was increased to 9489 rubles per month from January 1, 2018. New minimum wage established at the rate of 1 USD $=56.29$ rubles (rates of exchange 30 Jan 2018) is equivalent to 168.6 US dollars in a five-day working week with an 8-hour working day which corresponds to an hourly payment of less than 1 US dollar per hour or less than 8 US dollars per day, which is extremely far from the minimum wage set by the ILO - 4 US dollars per hour. For comparison, in the US, the minimum wage is 7.25 US dollars per hour, in China this level is 1.4 US dollars ( 8 yuan), in Japan - 6.88 US dollars (780 yen), in Germany - 8.5 euros, in Great Britain - 10.13 US dollars (6.5 euros), Australia - 12.28 US dollars, Poland 2.63 US dollars (10.12 zł) per hour. Russia's level of minimum hourly wage corresponds to Colombia and Brazil (1 and 0.95 US dollars per hour, respectively) [7].

According to the law, the minimum wage should not be less than the subsistence minimum of the working age population, but in practice, this is not the case (according to data for the 3rd quarter of 2017, the subsistence minimum for the working age population was 11,160 rubles per month [8]). In Russia, the federal minimum wage is assumed to be $85 \%$ of the working age population subsistence minimum from January 1, 2018, and from January 1, 2019, the indicators assumed to be equalized. Regional authorities establish the subsistence minimum based on not only standard indicators. They must take into account local features and need of the federal entities population.

In fact, the subsistence minimum is the value of living in Russia for different categories of people (working age population, retirees, children) and it represents the cost of the minimum set of products, things and services that a person needs. At least one time per five years the government decides what the subsistence minimum consists of and determines what should be included to consumer basket, which would provide a normal standard of living for a person. The subsistence minimum is calculated quarterly at the federal and regional levels, but its publication is significantly delayed. Thus, the third quarter of 2017 subsistence minimum was published in December 2017, and this indicator for the fourth quarter will be announced in March 2018. According to the 3rd quarter of 2017 
data, at January 1, 2018, the subsistence minimum in Russia was [8]: 10328 rubles per capita (183.5 US dollars calculated at the rate of 1 US dollar $=56.29$ rubles); 11160 rubles for the working age population (198 US dollars); 8496 rubles for retirees (151 US dollars); 10181 rubles for children (181 US dollars).

In addition, in the year to 2017 in Russia at the federal level the following social guarantees were established: the retirement pension base part (4805.1 rubles per month); disability pension of III group (2402.6 rubles per month), II and I groups (4805.1 rubles per month); in case of loss of the breadwinner (2402.6 rubles per month); a lumpsum social benefit for burial (5562 rubles); a lump-sum benefit for women who registered in medical institutions in the early stages of pregnancy (613.14 rubles); a lump-sum benefit for the birth of a child and a lump-sum benefit for placement of a child to the foster family (16350.33 rubles); monthly benefit for the period of leave to take care of a child before reaching the age of 1.5 years for the care of the first child (3065.69 rubles per month), for the care of the second child and subsequent children (6131.37 rubles per month), the maximum amount of the benefit for care (23120,66 rubles. per month); monthly double-amount benefit for child care until the child reaches the age of three years for citizens exposed to radiation due to the Chernobyl nuclear disaster (6324 rubles); monthly benefit for a child of a military serviceman passing military service on conscription (11096.76 rubles per month); monthly payments to unemployed working age persons caring for a disabled child under the age of 18 or I group disabled from the childhood - to the parent (adoptive parent) or guardian (trustee) (5500 rubles per month) and other persons (1200 rubles per month); the minimum amount of the unemployment benefit ( 850 rubles per month); the amount of state academic scholarships for students enrolled in higher education educational programs (1,340 rubles per month) and secondary vocational education (487 rubles per month); generic certificate (11,000 rubles); maternal family capital (453026 rubles). Since January 1,2018 , monthly payments for the birth of the first child in the amount of the subsistence minimum for children established in the region have been introduced (average amount in Russia in 2018 will be about 10500 rubles per month). It is a targeted payment that takes into account the criterion of need - the income of the whole family should be less than 1.5 of the subsistence minimum value of for the adult population. As we can see, the presented amounts of federal social guarantees, intended to provide recipients with means of subsistence, are below the subsistence minimum.

Most of social benefits do not take into account the current financial well-being of the recipient and they are provided without the criterion of need confirmation. Only $41 \%$ of those who need help receive the targeted benefits, which are assigned taking into account the income level [9]. 19\% of truly poor people (whose income per family is lower than the substance minimum) in Russia do not receive social support [10]. At the same time, $87 \%$ of those who use all kinds of benefits do not really need them.

Experts suggest that there is many of those who for various reasons are not able to "communicate with the social protection authorities" among poor people who do not receive social support, while the appointment of social assistance involves applying to social protection agencies for it. If there are no any appeals, the social protection authorities do not initiate communication with citizens themselves. There is a problem of citizens' awareness in terms of their social benefits. Mainly, those who do not own new information technologies often face it. Meanwhile, there are no such structures in
Russia that would monitor the situation of potentially vulnerable categories of citizens and inform them about possible sources of social assistance.

Specialists note that, in general, $3 \%$ of Russia's GDP is spent on social protection, while "general deficit of income for the poor is only $1 \%$ of GDP."

That means, in case of "correctly allocating at least a third of the social costs, it become possible solve the problem of poverty". According to calculations, each ruble spent on social support reduces the income deficit of the poor to a maximum of 28 kopecks [9]. In value terms, the budget system (including extra-budgetary funds) for financing the social protection system for Russians in 2017 amounted to 4.8 trillion rubles, of which 1.33 trillion rubles at the expense of the federal budget, 1.6 trillion rubles at the expense of state nonbudgetary funds, 534 million rubles at the expense of regional budgets, 1.87 trillion rubles at the expense of local budgets. This is equivalent to the following figures, respectively: $28 \%, 33.5 \%, 0.01 \%$ and $39 \%$.

Combining federal and regional measures of social protection leads to the fact that territorially Russians have different degrees of social protection (see Table 1).

Social assistance regional differentiation is very high, because social support comes from regional budgets. At the same time, social support coverage varies greatly by region: from less than $20 \%$ of the population in the Khanty-Mansiysk Autonomous District and the Kaluga Region, to $80-90 \%$ of the population in Chechnya, Buryatia, Veliky Novgorod, Krasnoyarsk, Dagestan and Kamchatka. The targeted payments share in the poorest people income does not exceed $2 \%$ on average by regions [9].

C. Social protection system improvement: the social legislation codification

Differentiation of regions in terms of their population social protection is inevitable, but it is possible to make the social protection system more effective and efficient. The authors the social protection system improvement in Russia in several areas: 1) the social legislation codification; 2) optimization of state social protection measures.

The enactment of social protection legislation of Russians at the federal, regional and local levels is heterogeneous. It can be explained by the financial independence of regional and local budgets, as well as by the different social and economic development levels of a particular territory with different social problems, to solving of which regional and municipal social policies are directed.

Thus, in most of the Federation entities and municipalities there are several dozen of simultaneously effective normative documents regulating the population social protection. The enactment of social protection legislation is fragmented, cumbersome, ambiguous. It complicates the administering process of state and municipal expenditures in this area and significantly increases the budget process opacity despite the open budget concept introduced into Russian practice. It also makes the consumption of social protection products by wide layers of the population inaccessible, because most of them do not have access to information about all the measures, privileges and guarantees they should receive. There is a strong need for social legislation codification at all government levels. 
TABLE I. REGIONAL SOCIAL BENEFITS DIFFERENTIATION, IN RUBLES

\begin{tabular}{|c|c|c|c|c|c|c|c|c|}
\hline Social benefits & CFD & NWFD & SFD & NCFD & PFD & UFD & Siberian FD & FEFD \\
\hline $\begin{array}{c}\text { Social benefit for the birth of the } \\
\text { third child and subsequent } \\
\text { children until the child reaches } 3 \\
\text { y.o. }\end{array}$ & $\begin{array}{l}\text { Min 0 } \\
\text { Max } 10370\end{array}$ & $\begin{array}{l}\text { Min } 8807 \\
\text { Max } 21076\end{array}$ & $\begin{array}{l}\text { Min } 0 \\
\text { Max } 10238\end{array}$ & $\begin{array}{l}\text { Min } 0 \\
\text { Max } 6003\end{array}$ & $\begin{array}{l}\text { Min 0 } \\
\text { Max } 9623\end{array}$ & $\begin{array}{l}\text { Min } 6300 \\
\text { Max } 15651\end{array}$ & $\begin{array}{l}\text { Min 0 } \\
\text { Max } 10940\end{array}$ & $\begin{array}{l}\text { Min } 0 \\
\text { Max } 20780\end{array}$ \\
\hline Pensions awarded, per month & $\begin{array}{l}\text { Min } 16021 \\
\text { Max } 18450\end{array}$ & $\begin{array}{l}\text { Min } 16761 \\
\text { Max } 24387\end{array}$ & $\begin{array}{l}\text { Min } 15585 \\
\text { Max } 17644\end{array}$ & $\begin{array}{l}\text { Min } 14680 \\
\text { Max } 16115\end{array}$ & $\begin{array}{l}\text { Min } 16011 \\
\text { Max } 17323\end{array}$ & $\begin{array}{l}\text { Min } 16414 \\
\text { Max } 23805\end{array}$ & $\begin{array}{l}\text { Min } 16115 \\
\text { Max } 18614\end{array}$ & $\begin{array}{l}\text { Min } 17109 \\
\text { Max } 27568\end{array}$ \\
\hline - labour veterans & $\begin{array}{l}\text { Min } 156 \\
\text { Max } 837\end{array}$ & $\begin{array}{l}\text { Min } 444 \\
\text { Max } 1650\end{array}$ & $\begin{array}{l}\text { Min 0 } \\
\text { Max } 1070\end{array}$ & $\begin{array}{l}\text { Min 0 } \\
\text { Max } 1429\end{array}$ & $\begin{array}{l}\text { Min } 0 \\
\text { Max } 1082\end{array}$ & $\begin{array}{l}\text { Min } 351 \\
\text { Max } 1249 \\
\end{array}$ & $\begin{array}{l}\text { Min } 0 \\
\text { Max } 808\end{array}$ & $\begin{array}{l}\text { Min 0 } \\
\text { Max } 1208\end{array}$ \\
\hline $\begin{array}{c}\text { - rehabilitated persons and } \\
\text { persons recognized as political } \\
\text { repressions victims }\end{array}$ & $\begin{array}{l}\text { Min } 95 \\
\operatorname{Max} 1300\end{array}$ & $\begin{array}{l}\text { Min } 360 \\
\text { Max } 1846\end{array}$ & $\begin{array}{l}\text { Min } 0 \\
\text { Max } 1250\end{array}$ & $\begin{array}{l}\text { Min } 0 \\
\text { Max } 1425\end{array}$ & $\begin{array}{l}\text { Min 0 } \\
\text { Max } 2449\end{array}$ & $\begin{array}{l}\text { Min } 178 \\
\text { Max } 1284\end{array}$ & $\begin{array}{l}\text { Min 0 } \\
\text { Max } 789\end{array}$ & $\begin{array}{l}\text { Min } 0 \\
\text { Max } 4892\end{array}$ \\
\hline
\end{tabular}

CFD - Central Federal District; NWFD - North-West Federal District; SFD - Southern Federal District; NCFD - North-Caucasian Federal District; PFD - Privolzhsky Federal District; UFO - the Urals Federal District; Siberian FD - Siberian Federal District; FEFD - Far-Eastern Federal District;

* - regional maternity capital payments go in addition to the federal average payment in the district.

In addition, experts note [5] that sometimes the social protection system, in spite of the personalization of benefits and support measures prohibition, allocates an individual family or a particular individual to an independent category of social assistance recipients. Such violations often occur in regional and municipal regulatory documents, when a governor or city mayor personal order establishes a monthly allowance or an additional payment for a specific citizen's pension, for example, "for significant contribution to the socioeconomic development of the region". The social legislation codification will allow to reduce such situations to a minimum.

The main objectives of the Social Code creation are the following [11]: the social legislation terminology unification; strengthening the targeted component - working out and introducing a clear, understandable for people approach in terms of what social support measures and under what conditions a persona quires a right to receive social support; introduction of objective criteria of need; an increase in the amount of social payments for families with children with low income and those who, for objective reasons, can not independently overcome a difficult life situation; increasing the spending budget funds efficiency; national social legislation and international law harmonization.

Nowadays the social legislation is codified (meaning the federal entities social codes are in effect) in four regions of the Russian Federation: St. Petersburg [12], Volgograd Region [13], Yaroslavl Region [14], Belgorod Region [15]. In these social codes, a mechanism for financing social expenditures is established in the context of expenditures for the additional and non-supplementary measures of social support and assistance implementation.

Nowadays other entities authorities consider the social protection of the population codification, for example, in Moscow [16], KhantyMansiysk, Leningrad Oblast [17]. Experts have noted the need for the the Social Code of the Russian Federation creation since the early 2000s $[18,19]$.

The authors note the necessity of adoption an all-Russian Social Code with an all social guarantees full list, federal social protection measures and a possible regional measures list (similar to the practice of the Russian Federation Tax Code). The corresponding Social Codes are necessary to be adopted at the regional and municipal levels. The structure of the existing Social Codes analysis has shown that there is no unified approach to the social support measures classification among regional legislators. The unified structure development of such codes becomes a separate direction for the rulemaking development, and the economic justification for the benefits and measures appropriateness and amount is a direction for the further methodological basis development for regional social protection system of the population.

D. Improvement of the social protection system of Russians: social protection measures optimization

State social protection measures optimization should be carried out in at least two ways: 1) reducing the measures list and increasing their amounts; 2) strengthening the social protection of citizens targeting through the family-oriented criteria of need introduction.

Reducing the social protection measures list and increasing their amounts should affect both federal guarantees and local supplementary measures. The analysis showed that a number of minimum social guarantees of federal, regional and local levels are small in average amounts paid. There are different measures to support families with children - monthly child benefits, which in many regions are 90-150 rubles, various targeted payments to schoolchildren, for meals at school, compensation for payment in pre-school institutions, holiday payments to the New Year, Family Day, September 1st and even Easter (regardless of religion and religious beliefs), compensation and benefits for housing and communal services, payments for the birth of a child and when a child reaches a certain age, plus services and benefits in kind, for example, free medicines, catering, free or discounted passage, discounted vacation, etc., Support for families with children only in Moscow is 17 social benefits and 7 measures in kind provided without taking into account the real family need [5]. Social support measures are insignificant in the family budgets of many recipients, while their mass character is significant for budgetary system [20].

The authors suggest that the state social protection measures reduction should be accompanied by transition to program-targeted financing methods, with an increase in the social protection targeting not for individuals, but for their households (the economic family projection). The authors consider household as one or more individuals living together and leading a joint budget [21].

The family-oriented policy should become a basis of the country social and demographic policy [22]. At the same time, we propose to 
create a "social treasury" as a system combining various aid recipients. Such a system will allow to collect information on all payments to each household [9]. Nowadays this information is so fragmented that it is difficult to understand the real family need in the social assistance provided.

When assessing the need, the following criteria should be taken into account: household income and property security. The average per capita income and property provision per one average household in the region could be the threshold value. Introducing the recipient household property security criterion, we rely on the experience of the Volgograd region, which shows that the use of only one criterion - the recipient's income is ineffective, since in the case of the reciprocal verification of the same recipient, according to the property security criterion, it turned out that among "poor" recipients (in terms of their income) there are owners of expensive cars, several real estate objects and even yachts [5].

The targeted social assistance introduction, as the other countries experience, can quickly bring results. According to the World Bank, it's possible for three or four years [5].

On one hand, strengthening of social assistance targeting the is possible with reducing categorical benefits (often they are federal ones), and on the other hand, with introducing complex need criteria (taking into account income and expenditure level - gross and per capita, and also taking into account the household members property security criterion). At the same time, we consider it necessary to preserve the current trends in public services standardization in the social sphere, the development of the remote mode technologies for social services applying, the "single window" and multifunctional assistance centers for the population practice.

\section{CONCLUSION}

An effective social protection system of the population in the region is a factor of its sustainable and competitive development, since the population well-being, its protection level against social risks creates a favorable environment for the development of human resources, which acts as the basis for the region's economy functioning.

The high regional differentiation in Russia in terms of the social protection level, despite the base values established by the federal authorities, creates territorial imbalance in the human resources development throughout the country that negatively affects regional economies.

The measures proposed by the authors will not only promote territorial equalization of the rights of Russians to social protection, but also will allow to optimize expenses of regions on social payments and privileges maintenance at the expense of their nonrational expenses exception (improving the social protection system by introducing social codification and unification, reducing the overall number of social protection measures and strengthening their targeting, with the parallel family-oriented criteria for the need introduction). There by, there will be created a basis for the social protection provision to the category of citizens who most need it, as opposed to the current situation.

In addition to the ways of the social protection system improvement described in this article, the development of systematic approaches to assessing the functioning of regional systems effectiveness for the social protection of Russians should be defined as forward-looking areas of social protection methodology improvement.

\section{References}

[1] Yu.A Fridman, G.N. Rechko and Yu.A. Pisarov [Yu.A Fridman, G.N. Rechko i Yu.A. Pisarov], "The Algorithm of estimation of competitiveness of region" [Algoritm otsenki konkurentosposobnosti regiona], Vestnik NSU. Series: Social and economic Sciences [Vestnik NGU. Seriya: Sotsial'no-ekonomicheskie nauki], vol. 14, no. 4, pp.111124,2014

[2] P. A. Sorokin [P. A. Sorokin], "Person. Civilization. Society." [Chelovek. Tsivilizatsiya. Obshchestvo], Moscow: Politizdat, 1992. $543 \mathrm{p}$.

[3] A concise dictionary of sociology [Kratkii slovar' po sotsiologii], Moscow: Politizdat, 1988, 479 p.

[4] V.I. Akopov, Yu.A. Gadzhiev and V.A. Sidorova [V.I. Akopov, Yu.A. Gadzhiev i V.A. Sidorova], "Problems of growth of welfare of the population of the Northern region" [Problemy rosta blagosostoyaniya naseleniya severnogo regiona], Syktyvkar, 2004. 227 p.

[5] A. Zotin [A. Zotin], "The Nameless Need. Who gets state social assistance" [Bezymyannaya nuzhda. Komu dostaetsya gosudarstvennaya sotsial'naya pomoshch]. Available at: https://www.kommersant.ru/doc/3112912

[6] SMIC from January 1, 2018 in Russia by region (table) from January 9, 2018 [MROT s 1 yanvarya 2018 goda v Rossii po regionam (tablitsa) ot 9 yanvarya 2018]. Available at: https://www.26-2.ru/art/351686-mrot2018-po-regionam-tablitsa

[7] Minimum hourly wages in different countries [Minimal'naya pochasovaya zarabotnaya plata $v$ raznykh stranakh mira]. Available at: http://infomaniya.com/minimalnaya-pochasovaya-zarabotnaya-plata-vraznyih-stranah-mira/

[8] Living wage 2018 of January 4, 2018 [Prozhitochnyi minimum 2018 ot 4 yanvarya 2018]. Available at: https://www.gazetaunp.ru/articles/52070-projitochnyy-minimum-2018

[9] Research Institute of the Ministry of Finance and the World Bank: 87\% of recipients of benefits and benefits do not need them [NII Minfina i Vsemirnyi bank: $87 \%$ poluchatelei l'got i posobii $\mathrm{v}$ nikh ne nuzhdayutsya]. Available at: https://www.miloserdie.ru/news/niiminfina-i-vsemirnyj-bank-87-poluchatelej-lgot-i-posobij-v-nih-nenuzhdayutsya/

[10] V. Nodelman [V. Nodel'man], "State aid does not reach the poor" [Gosudarstvennaya pomoshch' ne dokhodit do bednykh]. Available at: http://iz.ru/news/635068

[11] The social code is a real tool in the fight against poverty [Sotsial'nyi kodeks - eto real'nyi instrument $\mathrm{v}$ bor'be s bednost'yu]. Available at: http://fedpress.ru/interview/1716829

[12] The Social Code of St. Petersburg: St. Petersburg Law of November 22, 2011 N 728-132 [Sotsial'nyi kodeks Sankt-Peterburga : zakon SanktPeterburga ot 22 noyabrya 2011 goda N 728-132]. Available at: http://subsidii.net

[13] Social Code of the Volgograd Region: Volgograd Region Law of December 31, 2015 No. 246-OD [Sotsial'nyi kodeks Volgogradskoi oblasti : zakon Volgogradskoi oblasti ot 31 dekabrya 2015 goda №246OD] - Available at: https://rg.ru/2016/03/26/volgograd-zakon246-regdok.html

[14] Social Code of the Yaroslavl Region: Yaroslavl Region Law of December 19, 2008 No. 65-Z [Sotsial'nyi kodeks Yaroslavskoi oblasti : zakon Yaroslavskoi oblasti ot 19 dekabrya 2008 goda №65-z]. Available at: http://docs.cntd.ru/document/934023342

[15] Social Code of the Belgorod Region: Belgorod Region Law No. 165 of December 28, 2004 [Sotsial'nyi kodeks Belgorodskoi oblasti : zakon Belgorodskoi oblasti ot 28 dekabrya 2004 goda №165]. Available at: http://docs.cntd.ru/document/469022331

[16] N. Bakhareva [N. Bakhareva], "For Moscow they will write a social code" [Dlya Moskvy napishut sotsial'nyi kodeks]. Available at: http://mosday.ru/news/item.php?930505\&view=full

[17] We are discussing the draft of the Social Code of the Leningrad Region [Obsuzhdaem proekt Sotsial'nogo kodeksa Leningradskoi oblasti]. Available at: http://social.lenobl.ru/napdelo/soc_kod

[18] O.P. Frolov [O.P. Frolov], "Social Code in the system of state support of the population of Russia" [Sotsial'nyi kodeks v sisteme gosudarstvennoi 
podderzhki naseleniya Rossii], Staff of the enterprise [Kadry predpriyatiya], vol, 1, January 2013. Available at: http://finpress.ru/library/728/31525/

[19] Preparation of the social code of the Russian Federation - the next stage of codification of the Russian legislation [Podgotovka sotsial'nogo kodeksa RF - ocherednoi etap kodifikatsii Rossiiskogo zakonodatel'stva]. Available at: http://dis.ru/library/564/25211/

[20] E.I. Andreeva and D.G. Bychkov [E.I. Andreeva i D.G. Bychkov], "Universal Poverty Handbook: The Experience of Foreign Countries and Perspectives in Russia" [Universal'noe posobie po bednosti: opyt zarubezhnykh stran i perspektivy $v$ Rossii], Scientific Research Financial Institute. Financial Journal [Nauchno-issledovatel'skii finansovyi institut. Finansovyi zhurnal], vol. 6(28), pp. 24-33, June 2015.

[21] L.A. Mytareva, L.V. Grigorieva, E.A. Shkarupa, G.V. Portnova and A.A.Maletsky [L.A.Mytareva, L.V. Grigor'eva, E.A. Shkarupa, G.V.Portnova i A.A.Maletskii], "Potential of the finance of the population of the region: concept, structure, features (on the example of the Volgograd region)" [Potentsial finansov naseleniya regiona: ponyatie, struktura, osobennosti (na primere Volgogradskoi oblasti)]: collective. Monography, Volgograd: Publishing house "VolSU", 2014.

[22] V.A. Zimin and G.A. Morozova [V.A. Zimin i G.A. Morozova], "Social policy in the region" [Sotsial'naya politika $\mathrm{v}$ regione], Advances in modern science [Uspekhi sovremennoi nauki], vol. 1, part 7, pp. 144148, 2017. 